\title{
FAKTOR-FAKTOR YANG MEMPENGARUHI PROFITABILITAS PADA PERUSAHAAN PERBANKAN YANG TERDAFTAR DI BURSA EFEK INDONESIA
}

\author{
Muhammadinah \\ mdinah76@gmail.com
}

\begin{abstract}
This study aims to determine the factors that affect the profitability of the banking company listed on the Jakarta Stock Exchange. The population in this study are all commercial banks that are listed in the Indonesia Stock Exchange period 2014 as many as 40 banks. The samples in this study using purposive sampling method, as many as 40 companies. The analysis technique used in this research is multiple regression. The results showed that together variable CAR and FDR significant effect on profitability, but only partially FDR variables that significantly influence profitability.
\end{abstract}

Keywords: Capital Adequacy Ratio, Financing to Deposit Ratio and Profitability

\section{PENDAHULUAN}

Menurut Undang-Undang RI Nomor 10 Tahun 1998 tentang Perbankan, perbankan adalah segala sesuatu yang menyangkut tentang bank, mencakup kelembagaan, kegiatan usaha, serta cara dan proses dalam melaksanakan kegiatan usahanya. Sedangkan bank adalah badan usaha yang menghimpun dana dari masyarakat dalam bentuk simpanan dan menyalurkannya kepada masyarakat dalam bentuk kredit dan atau bentuk-bentuk lainnya dalam rangka meningkatkan taraf hidup rakyat banyak.

Bank merupakan perusahaan yang bergerak dalam usaha jasa, yang mana kepercayaan masyarakat akan menempati porsi yang sangat besar dalam menjaga kelangsungan hidupnya. Sebagai lembaga kepercayaan, bank dalam operasinya lebih banyak menggunakan dana dari masyarakat dibanding dengan modal sendiri dari pemilik atau pemegang saham, oleh karena itu pengelola bank dalam melakukan usahanya dituntut untuk dapat menjaga keseimbangan antara pemeliharaan likuiditas yang cukup dengan pencapaian rentabilitas yang wajar, serta pemenuhan modal yang memadai

Kinerja merupakan hal yang sangat penting bagi perusahaan, karena bisnis perbankan adalah bisnis kepercayaan, maka bank harus mampu menunjukkan kredibilitasnya sehingga akan semakin banyak masyarakat yang bertransaksi di bank tersebut, salah satunya melalui peningkatan profitabilitas. Bank yang selalu dapat menjaga kinerjanya dengan baik terutama tingkat profitabilitas yang tinggi dan mampu membagikan deviden dengan baik serta prospek usahanya dapat selalu berkembang dan memenuhi ketentuan prudential banking regulation dengan baik, maka kemungkinan nilai saham dari bank yang bersangkutan di pasar sekunder dan jumlah dana pihak ketiga yang berhasil dikumpulkan juga akan meningkat. 
Di samping itu, hubungan antara bank dengan nasabahnya di dalam sistem perbankan syariah adalah hubungan kemitraan antara pemilik dana dengan pengelola dana bukan hubungan debitur dengan kreditur. Sehingga tingkat laba bank tidak saja berpengaruh terhadap tingkat bagi hasil untuk para pemegang saham tetapi juga berpengaruh terhadap hasil yang dapat diberikan kepada nasabah penyimpan dana. Itulah sebabnya penting bagi bank untuk terus meningkatkan kinerjanya.

Profitabilitas dapat dikatakan sebagai salah satu indikator yang paling tepat untuk mengukur kinerja suatu perusahaan. Karena kemampuan perusahaan dalam menghasilkan laba dapat menjadi tolok ukur kinerja perusahaan tersebut. Semakin tinggi profitabilitasn

ya, semakin baik pula kinerja keuangan perusahaan.

Penilaian kinerja keuangan perbankan merupakan salah satu faktor yang penting bagi perbankan untuk melihat bagaimana bank tersebut dalam melakukan kinerjanya apakah sudah baik atau belum. Selain itu penilaian juga dapat digunakan untuk mengetahui seberapa besar profitabilitas atau keuntungan bank dengan membandingkan hasil laba pada tahun tertentu dengan laba tahun-tahun sebelum dan sesudahnya atau membandingkan kinerja perbankan yang satu dengan perbankan yang lainnya. Pada umumnya penilaian kinerja keuangan suatu bank bisa dilihat dari laporan keuangannya yang berasal dari perhitungan rasio keuangannya. ${ }^{1}$

Untuk meningkatkan kinerja bank maka harus didorong dengan eksistensi bank di Indonesia. Maka untuk itu perlu diadakan pengawasan pembinaan usaha agar perkembangan bank dapat berjalan sesuai dengan yang diharapkan. Tujuan pembinaan dan pengawasan bank menurut pasal 29 ayat 2 Undang- Undang Republik Indonesia No. 10 tahun 1998, yaitu: bank wajib memelihara tingkat kesehatan bank sesuai dengan ketentuan kecukupan modal, kualitas aset, kualitas manajemen, likuiditas, rentabilitas, solvabilitas, dan aspek lain yang berhubungan dengan usaha bank, dan wajib melakukan kegiatan usaha sesuai dengan prinsip kehati-hatian.

Sesuai dengan Surat Edaran BI No. 6/23/DPNP tanggal 31 Mei 2004, ROA digunakan untuk mengukur kemampuan bank dalam menggunakan asset yang dimilikinya untuk menghasilkan laba kotor, semakin tinggi nilai ROA maka akan semakin baik pula kemampuan atau kinerja bank tersebut. Return On Assets sebagai alat ukur kinerja bank mempunyai faktor-faktor yang dapat mempengaruhi profitabilitas suatu bank agar dapat meningkat atau dapat menurunkan profitabilitas suatu bank.

Salah satu faktor yang dapat mempengaruhi profitabilitas suatu bank adalah modal. Modal dalam hal ini diproksikan (alat ukurnya) dengan Capital Adequacy Ratio (CAR). CAR berkaitan dengan modal, peranan modal di dalam bank sangat penting, dimana kegiatan operasional bank dapat berjalan dengan baik apabila memiliki modal yang cukup. Bank yang tidak memiliki kecukupan

${ }^{1}$ Nugroho. 2011. Analisis Rasio Keuangan untuk menilai Kinerja Keuangan Perbankan Studi Empiris Bank Go Publik 2003-2004. Skripsi Akuntansi Universitas Muhammadiyah Surakarta 
modal maka bank tersebut bias dikatakan tidak sehat rasionya, sehingga bank tersebut masuk dalam kriteria bank dalam pengawasan khusus karena rasio kecukupan modal (CAR) nya di bawah standar yang ditetapkan Bank Indonesia. CAR yang ditetapkan bank indonesia adalah $8 \%^{2}$.

Tingkat CAR sangat mempengaruhi kepercayaan masyarakat terhadap bank, dimana kepercayaan masyarakat merupakan modal dasar bagi kelangsungan lembaga keuangan ini. Tingkat CAR yang ideal akan sangat menguntungkan bagi bank dan dapat meningkatkan kepercayaan masyarakat sebagai pemilik dana, sehingga masyarakat akan memiliki keinginan untuk menyimpan dana nya di bank. Sehingga, jika kepercayaan masyarakat tinggi maka akan dapat meningkatkan profitabilitas pada bank ${ }^{3}$.

Faktor lain yang mempengaruhi tingkat profitabilitas adalah Financing to Deposit Ratio (FDR). Financing to Deposit Ratio merupakan rasio yang digunakan untuk mengukur likuiditas suatu bank dalam membayar kembali penarikan dana yang dilakukan deposan dengan mengandalkan kredit yang diberikan sebagai sumber likuiditasnya, yaitu dengan cara membagi jumlah kredit yang diberikan oleh bank terhadap dana pihak ketiga. Semakin tinggi FDR maka semakin tinggi dana yang disalurkan ke dana pihak ketiga. Dengan penyaluran dana pihak ketiga yang besar maka pendapatan bank (ROA) akan semakin meningkat, sehingga FDR berpengaruh positif terhadap ROA.

\section{TINJAUAN TEORITIS}

\section{Profitabilitas}

\section{a. Pengertian Profitabilitas}

Profitabilitas merupakan kemampuan suatu perusahaan untuk mendapatkan laba (keuntungan) dalam suatu periode tertentu. Pengertian yang sama disampaikan oleh Husnan bahwa Profitabilitas adalah kemampuan suatu perusahaan dalam menghasilkan keuntungan (profit) pada tingkat penjualan, aset, dan modal saham tertentu ${ }^{4}$.

Sedangkan menurut Michelle \& Megawati Profitabilitas merupakan kemampuan perusahaan menghasilkan laba (profit) yang akan menjadi dasar pembagian dividen perusahaan ${ }^{5}$.

Prolitabilitas menggambarkan kemampuan badan usaha untuk menghasilkan laba dengan menggunakan seluruh modal yang dimiliki. Hal ini sesuai dengan pernyataan Shapiro "Profitability ratios measure managements

2 Defri. 2012. Pengaruh Capital Adequacy Ratio (CAR), Likuiditas dan Efisiensi Operasional Terhadap Profitabilitas Perusahaan Perbankan yang Terdaftar di BEI. Jurnal Manajemen. Vol 1. No 1.

${ }^{3}$ Sukarno \& Syaichu. 2006. Analisis Faktor - Faktor yang Mempengaruhi Kinerja Bank Umum di Indonesia. Jurusan Manajemen Falkutas Ekonomi dan Bisnis Universitas Diponegoro. Jurnal Studi Manajemen dan Organisasi. Volume 3, Nomer 2.

${ }^{4}$ Husnan. 2001. Manajemen Keuangan Teori dan Penerapan. (keputusan Jangka Pendek), Edisi keempat, BPFE, Yogyakarta.

${ }^{5}$ Michelle \& Megawati. 2005. Tingkat Pengembalian Investasi Dapat Diprediksi Melalui Profitabilitas, Likuiditas, dan Leverage. Kumpulan Jurnal Ekonomi_com. 
objectiveness as indicated by return on sales, assets and owners equity." Profitabilitas suatu perusahaan akan mempengaruhi kebijakan para investor atas investasi yang dilakukan. Kemampuan peurusahaan untuk menghasilkan laba akan dapat menarik para investor untuk menanamkan dananya guna memperluas usahanya, sebaliknya tingkat profitabilitas yang rendah akan menyebabkan para investor menarik dananya ${ }^{6}$. Sedangkan bagi perusahaan itu sendiri profitabilitas dapat digunakan sebagai evaluasi atas efektivitas pengelolaan badan usaha tersebut. Menurut Brigham "Profitability is the net result of a large number of policies and decision. The ratio examined thus far reveal some interesting thing about the wry the firm operates, but the profitability ratio show the combined objects of liquidity, asset management, and debt management on operating mult." "

Profitabilitas juga mempunyai arti penting dalam usaha mempertahankan kelangsungan hidupnya dalam jangka panjang, karena profitabilitas menunjukkan apakah badan usaha tersebut mempunyai prospek yang baik di masa yang akan datang. Dengan demikian setiap badan usaha akan selalu berusaha meningkatkan profitabilitasnya, karena semakin tinggi tingkat profitabilitas suatu badan usaha maka kelangsungan hidup badan usaha tersebut akan lebih terjamin. Seperti diungkapkan oleh Giulio Battazzi, Angelo Secchi, and Federico Tamagni dalam jurnalnya yang berjudul "Productivity, Profitabilty, and Financial Performance" menyatakan bahwa A comparative analysis of two crucial dimensions of firms performance: profitability and productivity, and find independently from the particular sector of activity and from financial conditions, there seems to be weak market pressure and little behavioral inclination for the more efficient and more profitable firms to grow faster. ${ }^{8}$

Rasio ini adalah rasio keuntungan bersih setelah pajak terhadap jumlah asset secara keseluruhan. Rasio ini merupakan suatu ukuran untuk menilai seberapa besar tingkat pengembalian (\%) dari asset yang dimiliki. Apabila rasio ini tinggi berarti menujukkan adanya efisiensi yang dilakukan oleh pihak manejemen.

Hanafi dan Halim menyatakan bahwa rasio Return on Assets (ROA) mengukur kemampuan perusahaan menghasilkan laba bersih berdasarkan tingkat asset tertentu' . Demikian juga Syamsudin mengatakan bahwa Return on Asset (ROA) merupakan pengukuran kemampuan perusahaan secara keseluruhan di dalam menghasilkan keuntungan dengan jumlah keseluruhan aktiva yang tersedia

${ }^{6}$ Shapiro. 1991. Analisis Pengaruh Return On Equity, Insider Ownership, Investment Opportunity Set, Firm Size, Cash Flo, dan Debt Ratio terhadap Dividend Payout Ratio (Studi Empiris Perusahaan Manufaktur di BEI Periode 2004-2007)”. Skripsi Ekonomi Akuntansi, Universitas Diponegoro.

${ }^{7}$ Brigham. 1993. Intermediate Financial Management, Fourth, Fort Word, The Dyrden Press,: Harcourt Brace College Publisher

${ }^{8}$ Giulio Battazzi, Angelo Secchi, and Federico Tamagni. "Productivity, Profitabilty, and Financial Performance". Oxford JournalsEconomics \& Social Sciences Industrial and Corporate Change Volume 17, Issue 4Pp. $711-751$

${ }^{9}$ Hanafi dan Halim. 2003. Analisis Laporan Keuangan, Edisi. Kedua, Yogyakarta : STIE YKPN 
di dalam perusahaan, semakin tinggi rasio ini berarti semakin baik keadaan suatu perusahaan $^{10}$.

Return on Assets mengukur kemampuan perusahaan dalam memanfaatkan aktivanya untuk memperoleh laba. Menurut Dwi Prastowo (2008) rasio ini mengukur tingkat kembalian investasi yang telah dilakukan oleh perusahaan dengan menggunakan seluruh dana (aktiva) yang dimilikinya. Demikian juga menurut Robert C. Fink dan Ann Harrison, menyebutkan bahwa : "ROA as the same income a company generates during normal operation dividend by its total assets. This calculation determines how well a company is using its assets to generate income. ${ }^{11}$

Untuk menghitung ROA dapat digunakan rumus sebagai berikut:

$$
\text { ROA }=\frac{\text { Laba Bersih }}{\text { Total Asset }}
$$

Martono dan Harjito menambahkan bahwa, profitabilitas merupakan kemampuan perusahaan untuk memperoleh laba dari modal yang digunakan untuk menghasilkan laba tersebut". Kinerja manajerial dari setiap perusahaan akan dapat dikatakan baik apabila tingkat profitabilitas perusahaan yang dikelolanya tinggi ataupun dengan kata lain maksimal, dimana profitabilitas ini umumnya selalu diukur dengan membandingkan laba yang diperoleh perusahaan dengan sejumlah perkiraan yang menjadi tolak ukur keberhasilan perusahaan. Adanya kemampuan memperoleh laba dengan menggunakan semua sumber daya perusahaan maka tujuan - tujuan perusahaan akan dapat tercapai. Penggunaan semua sumber daya tersebut akan memungkinkan perusahaan untuk memperoleh laba yang tinggi. Laba merupakan hasil dari pendapatan oleh penjualan yang dikurangi dengan beban. ${ }^{12}$

Munawir, profitabilitas menunjukkan kemampuan perusahaan untuk menghasilkan laba selama periode tertentu". Kinerja manajerial dari setiap perusahaan akan dapat dikatakan baik apabila tingkat profitabilitas perusahaan yang dikelolanya tinggi ataupun dengan kata lain maksimal, dimana profitabilitas ini umumnya selalu diukur dengan membandingkan laba yang diperoleh perusahaan dengan sejumlah perkiraan yang menjadi tolak ukur keberhasilan perusahaan seperti jumlah aktiva perusahaan maupun penjualan investasi, sehingga dapat diketahui efektifitas pengelolaan keuangan dan aktiva oleh perusahaan. $^{13}$

Brigham, Profitabilitas adalah hasil bersih dari serangkaian kebijakan dan keputusan. Untuk dapat menjaga kelangsungan hidupnya, suatu perusahaan haruslah berada dalam keadaan menguntungkan (Profitable). Tanpa adanya keuntungan akan sangat sulit bagi perusahaan untuk menarik modal dari luar. Para

${ }^{10}$ Syamsudin. 2004. Manajemen Keuangan Perusahaan. Jakarta : PT Raja Grafindo Persada.

${ }^{11}$ Robert C. Fink dan Ann Harrison. 1999. Business Return on Investment, Journal of Return On Investment, Computerworld; Jun 21; vol 33, Iss 25; ABI/INFORM Global, pg. 72. (on line)

\footnotetext{
${ }^{12}$ Martono dan Harjito. 2011. Manajemen Keuangan, Yogyakarta, Ekonisia

${ }^{13}$ Munawir. 2004. Analisis Laporan Keuangan, Edisi Ke-4, Liberty, Yogyakarta
} 
kreditor, pemilik perusahaan dan terutama pihak manajemen perusahaan akan berusaha meningkatkan keuntungan ini, karena disadari betul betapa pentingnya arti keuntungan bagi masa depan perusahaan. Profitabilitas suatu perusahaan akan mempengaruhi kebijakan para investor atas investasi yag dilakukan. Kemampuan perusahaan untuk menghasilkan laba akan dapat menarik para investor untuk menanamkan dananya guna memperluas usahanya, sebaliknya tingkat profitabilitas yang rendah akan menyebabkan para investor menarik dananya. Sedangkan bagi perusahaan itu sendiri profitabilitas dapat digunakan sebagai evaluasi atas efektivitas pengelolaan badan usaha tersebut. ${ }^{14}$

Dalam kegiatan operasional perusahaan, profit merupakan elemen penting dalam menjamin kelangsungan perusahaan. Dengan adanya kemampuan memperoleh laba dengan menggunakan semua sumber daya perusahaan maka tujuan-tujuan perusahaan akan dapat tercapai. Pengguna semua sumber daya tersebut memungkinkan perusahaan untuk memperoleh laba yang tinggi. Laba merupakan hasil dari pendapatan oleh penjualan yang dikurangkan dengan beban pokok penjualan dan beban-beban lainnya. Tujuan penggunaan profitabilitas bagi perusahaan maupun bagi pihak luar perusahaan adalah sebagai berikut:

1. Untuk mengukur atau menghitung laba yang diperoleh perusahaan dalam satu periode tertentu

2. Untuk menilai posisi laba perusahaan tahun sebelumnya dengan tahun sekarang

3. Untuk menilai perkembangan laba dari waktu ke waktu

4. Untuk mengukur produktifitas dari seluruh dana perusahaan yang digunakan baik modal sendiri

5. Mengukur produktivitas seluruh dana perusahaan yang digunakan, baik modal pinjaman maupun modal sendiri.

6. Untuk mengukur produktifitas dari seluruh dana perusahaan yang digunakan.

7. Dan tujuan lainnya.

\section{b. CAR (Capital Adequacy Ratio)}

Menurut Dendawijaya CAR adalah " Rasio yang memperlihatkan seberapa jauh seluruh aktiva bank yang mengandung risiko (kredit, penyertaan, surat berharga, tagihan pada bank lain) ikut dibiayai dari dana modal sendiri bank disamping memperoleh dana - dana dari sumber - sumber di luar bank, seperti dana dari masyarakat, pinjaman, dan lain - lain. CAR merupakan indikator terhadap kemampuan bank untuk menutupi penurunan aktivanya sebagai akibat dari kerugian - kerugian bank yang di sebabkan oleh aktiva yang berisiko. ${ }^{15}$

Menurut Surat Edaran Bank Indonesia No.6/ 23./DPNP tanggal 31 Mei 2004 Lampiran 1a, rasio CAR dapat dirumuskan sebagai perbandingan antara modal bank terhadap aktiva tertimbang menurut risiko modal bank adalah total modal yang berasal dari bank yang terdiri dari modal inti dan modal pelengkap. Modal inti yaitu modal milik sendiri yang diperoleh dari modal disetor oleh pemegang saham. Modal inti terdiri dari modal disetor, agio saham, cadangan

\footnotetext{
${ }^{14}$ Brigham. 1993. Intermediate Financial Management, Fourth, Fort Word, The Dyrden Press,: Harcourt Brace College Publisher

${ }^{15}$ Dendawijaya. 2009. Manajemen Perbankan. Penerbit Ghalia Indonesia. Jakarta.
} 
umum, cadangan tujuan, laba ditahan, laba tahun lalu, laba tahun berjalan, dan bagian kekayaan anak perusahaan yang laporan keuangannya dikonsolidasikan. Modal pelengkap terdiri dari cadangan revaluasi aktiva tetap, cadangan penghapusan aktiva yang diklasifikasikan, modal kuasa, dan pinjaman subordinasi. Sedangkan ATMR merupakan penjumlahan ATMR aktiva neraca dengan ATMR administratif. Semakin tinggi CAR maka semakin baik kondisi sebuah bank Jika nilai CAR tinggi berarti bank tersebut mampu membiayai operasi bank, keadaan yang menguntungkan bank tersebut akan memberikan kontribusi yang cukup besar bagi profitabilitas.

Penyediaan modal minimum yang ditetapkan oleh pemerintah dalam penilaian kesehatan bank ini berubah-ubah sesuai dengan tingkat keperluan yang dianggap paling tepat. Misalnya, tingkat CAR yang ditetapkan oleh pemerintah untuk tahun 1999 minimal 8\% dan untuk tahun 2001 minimal 12\%. Pada prinsipnya, tingkat CAR ini disesuaikan

dengan ketentuan CAR yang berlaku secara internasional yaitu sesuai dengan standard yang dikeluarkan oleh Bank for International Settlement (BIS). Peningkatan CAR ini bertujuan untuk meningkatkan kinerja dan untuk memastikan prinsip kehati-hatian perbankan senantiasa terjamin.

Besarnya nilai CAR suatu bank dapat dihitung dengan rumus :

$$
\text { CAR }=\frac{\text { Modal }}{\text { ATMR }} \times 100 \%
$$

Menurut Rivai, modal adalah faktor penting bagi bank dalam rangka pengembangan usaha dan menampung kerugian. Agar mampu berkembang dan bersaing secara sehat, maka permodalannya perlu disesuaikan dengan ukuran internasional yang

dikenal dengan standar BIS (Bank for International Settlement) ${ }^{16}$. Modal terdiri dari modal inti dan modal pelengkap dengan penjelasan sebagai berikut ${ }^{17}$ :

1. Modal Inti, berupa:

a. Modal Disetor, yaitu modal yang telah disetor secara efektif oleh pemiliknya.

b. Agio Saham, yaitu selisih lebih setoran yang diterima oleh bank akibat harga saham yang melebihi nilai nominal.

c. Modal Sumbangan, yaitu modal yang diperoleh dari sumbangansumbangan saham, termasuk selisih antara nilai yang tercatat dengan harga jual apabila saham tersebut dijual.

d. Cadangan umum, yaitu cadangan dari penyisihan laba yang ditahan atau dari laba bersih setelah dikurangi pajak, dan mendapat persetujuan rapat anggota sesuai dengan ketentuan pendirian atau anggaran masing-masing bank.

${ }^{16}$ Rivai. 2007. Bank and Financial Institution Manajement, Jakarta : PT. Rajagrafindo Persada

${ }^{17}$ Susilo. 2000. Bank dan Lembaga Keuangan Lain, Salemba Empat,. Jakarta 
e. Cadangan tujuan, yaitu bagian laba setelah dikurangi pajak yang disisihkan untuk tujuan tertentu dan telah mendapat persetujuan rapat umum pemegang saham atau rapat anggota.

f. Laba yang ditahan, yaitu saldo laba bersih setelah dikurangi pajak yang oleh RUPS atau rapat anggota diputuskan untuk tidak dibagikan.

g. Laba tahun lalu, yaitu seluruh laba bersih tahun lalu setelah diperhitungkan pajak dan belum ditetapkan penggunaannya.

h. Laba tahun berjalan, yaitu 50 persen dari laba tahun buku berjalan dikurangi pajak. Apabila tahun berjalan bank mengalami kerugian, maka seluruh kerugian tersebut menjadi faktor pengurang dari modal inti.

2. Modal Pelengkap, berupa:

a. Cadangan revaluasi aktiva tetap, yaitu cadangan yang dibentuk dari selisih penilaian kembali aktiva tetap yang telah mendapat persetujuan Direktorat Jenderal Pajak.

b. Penyisihan penghasilan aktiva produktif, yaitu cadangan yang dibentuk dengan cara membebani laba rugi tahun berjalan. Cadangan ini dibentuk untuk menampung kerugian yang mungkin timbul akibat tidak diterimanya kembali sebagian atau seluruh aktiva produktif. Penyisihan penghapusan aktiva produktif yang dapat diperhitungkan sebagai modal pelengkap adalah maksimum 25 persen dari ATMR.

c. Modal Kuasi, yaitu modal yang didukung oleh instrument atau warkat yang memiliki sifat seperti modal.

d. Pinjaman subordinasi, yaitu pinjaman yang harus memenuhi berbagai syarat, seperti ada perjanjian tertulis antara bank dan pemberi pinjaman mendapat persetujuan dari Bank Indonesia, minimal berjangka lima tahun dan pelunasan sebelum jatuh tempo, harus ada Bank Indonesia

\section{c. Financing to Deposit Ratio (FDR)}

Financing to Deposit Ratio (FDR) merupakan rasio yang digunakan untuk mengukur likuiditas suatu bank dalam membayar kembali penarikan dana yang dilakukan deposan dengan mengandalkan pembiayaan yang diberikan sebagai sumber likuiditasnya, yaitu dengan cara membagi jumlah pembiayaan yang diberikan oleh bank terhadap Dana Pihak Ketiga (DPK).

Semakin tinggi Financing to Deposit Ratio (FDR) maka semakin tinggi dana yang disalurkan ke Dana Pihak Ketiga (DPK). Dengan penyaluran Dana Pihak Ketiga (DPK) yang besar maka pendapatan bank Return on Asset (ROA) akan semakin meningkat, sehingga Financing to Deposit Ratio (FDR) berpengaruh positif terhadap Return on Asset (ROA).

Berdasarkan ketentuan yang tertuang dalam Surat Edaran Bank Indonesia No.12/11/DPNP/2010, besarnya Financing to Deposit Ratio (FDR) yang mencerminkan likuiditas suatu bank yang sehat adalah $85 \%$ - 110\%. Apabila Financing to Deposit Ratio (FDR) suatu bank berada di atas atau di bawah $85 \%$ $110 \%$, maka bank dalam hal ini dapat dikatakan tidak menjalankan fungsinya sebagai pihak intermediasi (perantara) dengan baik

Kemudian jika rasio Financing to Deposit Ratio (FDR) bank mencapai lebih dari $110 \%$, berarti total pembiayaan yang diberikan bank tersebut melebihi 
dana yang dihimpun. Oleh karena dana yang dihimpun dari masyarakat sedikit, maka bank dalam hal ini juga dapat dikatakan tidak menjalankan fungsinya sebagai pihak intermediasi (perantara) dengan baik. Semakin tinggi Financing to Deposit Ratio (FDR) menunjukkan semakin riskan kondisi likuiditas bank, sebaliknya semakin rendah Financing to Deposit Ratio (FDR) menunjukkan kurangnya efektivitas bank dalam menyalurkan pembiayaan. Jika rasio Financing to Deposit Ratio (FDR) bank berada pada standar yang ditetapkan oleh Bank Indonesia, maka laba yang diperoleh bank tersebut akan meningkat (dengan asumsi bank tersebut mampu menyalurkan pembiayaannya dengan efektif).

Besarnya nilai FDR suatu bank dapat dihitung dengan rumus:

$$
\text { FDR }=\frac{\text { Pembiayaan yang diberikan }}{\text { Total dana pihak ketiga }} \times 100 \%
$$

Berdasarkan Surat Edaran Bank Indonesia No. 12/11/DPNP/2010, Financing to Deposit Ratio (FDR) merupakan perbandingan antara pembiayaan dengan dana pihak ketiga ditambah modal sendiri. Adapun dana pihak ketiga berupa $^{18}$ :

1. Titipan simpanan yang dijamin keamanan dan pengembaliannya tapi tanpa memperoleh imbalan atau keuntungan.

2. Partisipasi modal berbagi hasil dari berbagai risiko untuk investasi umum.

3. Investasi khusus dimana bank hanya berlaku sebagai manajer investasi untuk memperoleh fee dan investor sepenuhnya mengambil risiko atas investasi tersebut.

Menurut Muhammad, semakin tinggi rasio Financing to Deposit Ratio (FDR) tersebut memberikan indikasi semakin rendahnya kemampuan likuiditas bank yang bersangkutan. Hal ini disebabkan karena jumlah dana yang diperlukan untuk pembiayaan menjadi semakin besar. Semakin besar kredit maka pendapatan yang diperoleh naik, karena pendapatan naik secara otomatis laba juga akan mengalami kenaikan ${ }^{19}$.

\section{Kerangka Pemikiran}

Dalam menjalankan usahanya sebagai lembaga keuangan yang menjual kepercayaan dan jasa, setiap bank berusaha sebanyak mungkin menarik nasabah baru ataupun investor, memperbesar dananya dan juga memperbesar pemberian kredit dan jasanya. Sehingga peran perbankan sangat strategis. Namun, kesehatan dan stabilitas perbankan menjadi sesuatu yang sangat vital. Dimana bank yang sehat, baik secara individu, maupun secara keseluruhan sebagai suatu sistem, merupakan kebutuhan suatu perekonomian yang ingin tumbuh dan berkembang dengan baik. Tetapi, terganggunya fungsi intermediasi perbankan setelah

${ }^{18}$ Muhammad. 2005. Bank Syariah Problem dan Proses Perkembangan di Indonesia. Graha Ilmu:Yogyakarta.

${ }^{19}$ Muhammad. 2005. Bank Syariah Problem dan Proses Perkembangan di Indonesia. Graha Ilmu:Yogyakarta. 
terjadinya krisis perbankan di Indonesia telah mengakibatkan lambannya kegiatan investasi dan pertumbuhan ekonomi bank.

Manfaat bank yang begitu penting bagi perekonomian, maka setiap negara berupaya agar perbankan selalu berada dalam kondisi yang sehat, aman dan stabil. Namun, rendahnya kualitas perbankan tercermin dari lemahnya kondisi internal sektor perbankan, serta belum efektifnya pengawasan yang dilakukan oleh Bank Indonesia. Kuantitas bank yang banyak menciptakan persaingan yang semakin ketat dan kinerja bank yang menjadi rendah karena ketidakmampuan bersaing di pasar, sehingga banyak bank yang sebenarnya kurang sehat atau bahkan tidak sehat secara financial.

Profitabilitas merupakan indikator yang paling penting untuk mengukur kinerja suatu CAR atau kecukupan modal merupakan salah satu masalah yang dihadapi perbankan dalam sektor internal. Bank harus memelihara modal yang cukup untuk mendukung aktivitas pengambilan risiko (risk taking). Peranan modal sangat penting, dimana kegiatan operasional bank dapat berjalan dengan lancar apabila memiliki modal yang cukup, sehingga pada saat masa-masa kritis bank tetap aman karena memiliki cadangan modal di Bank Indonesia. Bank yang tidak memiliki kecukupan modal maka bank tersebut bisa dikatakan tidak sehat rasionya, sehingga bank tersebut masuk dalam kriteria bank dalam pengawasan khusus karena rasio kecukupan modal (capital adequacy ratio atau CAR)-nya di bawah standar yang ditetapkan Bank Indonesia (8\%). Sehingga kemampuan bank untuk survive pada saat mengalami kerugian dan juga mengakibatkan turunnya kepercayaan nasabah yang pada akhirnya dapat menurunkan profitabilitas bank. jika nilai CAR rendah maka profitabilitas (ROA) bank akan mengalami penurunan.

Selanjutnya likuiditas, likuiditas adalah kemampuan bank untuk membayar semua utang jangka pendeknya dengan alat-alat likuid yang dikuasainya. Likuiditas merupakan rasio untuk mengukur kemampuan bank dalam memenuhi kewajiban jangka pendeknya pada saat ditagih. Dengan kata lain, dapat membayar kembali pencairan dana deposannya pada saat ditagih serta dapat mencukupi permintaan kredit yang telah diajukan. Salah satu cara dalam mengukur likuiditas bank yaitu dapat diukur dengan FDR.

FDR mencerminkan kegiatan utama suatu bank yang dapat diartikan tingkat penyaluran kredit juga mempengaruhi besarnya nilai ROA, dimana rasio yang mengukur perbandingan jumlah kredit yang diberikan bank dengan dana yang diterima oleh bank. Semakin tinggi rasio ini, maka semakin tinggi dana yang disalurkan ke dana pihak ketiga, sehingga LDR yang meningkat dapat meningkatkan profitabilitas bank. Akan tetapi, semakin tinggi rasionya mengindikasikan rendahnya kemampuan likuiditas bank, hal ini karena jumlah dana yang diperlukan untuk membiayai kredit menjadi semakin besar.

Secara garis besar untuk menggambarkan faktor-faktor yang mempengaruhi profitabilitas pada perusahaan perbankan yang terdaftar di BEI dapat digambarkan dalam kerangka pemikiran sebagai berikut:

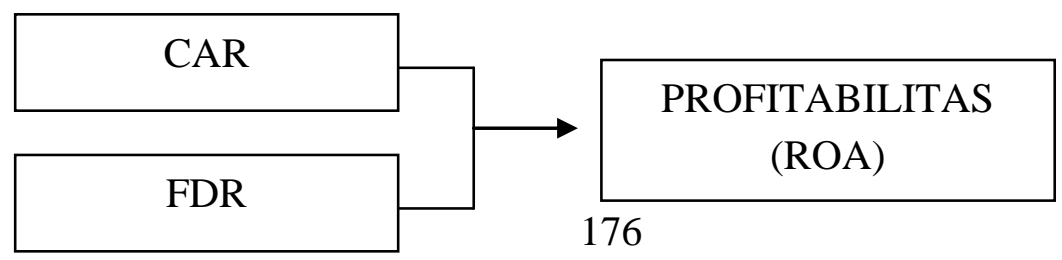




\section{Gambar 1 \\ Kerangka Pemikiran}

\section{Uji Hipotesis}

1. Pengaruh CAR Terhadap Profitabilitas Perusahaan Perbankan yang Terdaftar di BEI

Ho Variabel CAR tidak berpengaruh signifikan terhadap profitabilitas perusahaan Perbankan yang Terdaftar di BEI

Ha Variabel CAR berpengaruh signifikan terhadap profitabilitas perusahaan Perbankan yang Terdaftar di BEI

2. Pengaruh FDR Terhadap Profitabilitas Perusahaan Perbankan yang Terdaftar di BEI

Ho Variabel FDR tidak berpengaruh signifikan terhadap profitabilitas perusahaan Perbankan yang Terdaftar di BEI

Ha Variabel FDR berpengaruh signifikan terhadap profitabilitas perusahaan Perbankan yang Terdaftar di BEI

3. Pengaruh CAR dan FDR Terhadap Profitabilitas Perusahaan Perbankan yang Terdaftar di BEI

Ho Variabel CAR dan FDR tidak berpengaruh signifikan terhadap profitabilitas perusahaan Perbankan yang Terdaftar di BEI

Ha Variabel CAR dan FDR berpengaruh signifikan terhadap profitabilitas perusahaan Perbankan yang Terdaftar di BEI

\section{METODE PENELITIAN}

\section{Tempat Penelitian}

Penelitian ini dilaksanakan pada perbankan yang terdaftar pada Bursa Efek Indonesia Periode 2011 - 2014, dimana datanya berupa laporan keuangan yang dipublikasikan yang dapat di download di www.idx.co.id

\section{Populasi dan Sampel}

Populasi dalam penelitian ini adalah seluruh bank umum yang terdaftar dalam Bursa Efek Indonesia periode 2014 sebanyak 40 bank. Penentuan sampel dalam penelitian ini menggunakan metode purposive sampling, yaitu sampel ditarik sejumlah tertentu dari populasi emiten dengan menggunakan pertimbangan atau tertentu sehingga seluruh perusahaan perbankan diambil sebagai sampel yaitu sebanyak 40 perusahaan. 


\section{Jenis Penelitian}

Jenis penelitian ditinjau dari tingkat eksplanasinya ada 3 macam yaitu:

a. Penelitian deskriptif

Penelitian deskriptif penelitian yang dilakukan untuk mengetahui nilai variabel mandiri baik satu variabel atau lebih (independen) tanpa membuat perbandingan atau menghubungkan dengan nilai variabel lain.

b. Penelitian komparatif

Penelitian komparatif penelitian yang bersifat membandingkan, yang variabelnya masih sama dengan penelitian variabel mandiri tetapi lebih dari satu atau dalam waktu yang berbeda.

c. Penelitian asosiatif

Penelitian asosiatif penelitian yang bertujuan untuk mengetahui hubunggan antara dua variabel atau lebih.

Jenis penelitian yang digunakan dalam penelitian ini yaitu penelitian asosiatif yaitu penelitian yang dilakukan untuk mengetahui hubunggan antara dua variabel atau lebih.

\section{Jenis Data}

Ada dua jenis data yang digunakan dalam penelitian:

1. Data primer

Data primer merupakan sumber data penelitian yang diperoleh secara langsung dari sumber asli (tidak melalui perantara).

2. Data sekunder

Data sekunder yaitu sumber data penelitian yang diperoleh penelitian secara langsung melalui media perantara (diperoleh dan dicatat oleh pihak lain).

Jenis data yang digunakan dalam penelitian ini adalah data primer dan data sekunder. Data primer dalam penelitian ini diperoleh melalui internet dimana untuk memperoleh data yang diperlukan. Data sekunder dalam penelitian ini berupa jurnal dan penelitian-penelitian terdahulu.

\section{Metode Pengumpulan Data} menjadi:

Berdasarkan cara pengumpulannya teknik pengumpulan data dibagi

1. Pengamatan (Observasi)

Pengamatan adalah metode pengumpulan data dimana peneliti mencatat informasi sebagaimana yang mereka saksikan selama penelitian.

2. Survey

Survey adalah metode pengumpulan data dengan menggunakan instrumen untuk meminta tanggapan dari responden tentang sampel.

3. Wawancara

Wawancara yaitu bentuk komunikasi langsung antara peneliti dan responden. Komunikasi langsung dalam bentuk Tanya jawab dalam hubungan tatap muka, sehingga gerak mimik responden merupakan media yang melengkapi kata-kata secara variabel.

4. Kuesioner (angket) 
Kuesioner (angket) hanya berbeda dalam bentuknya. Pada kuesioner pertanyaan disusun dalam bentuk kalimat Tanya, sedangkan pada angket pertanyaan disusun dalam kalimat pertanyaan dengan opsi jawaban yang tersedia.

5. Metode Dokumentasi

Dokumentasi adalah catatan tertulis tentang berbagai kegiatan atau peristiwa pada waktu yang lalu.

Teknik pengumpulan data yang digunakan dalam penelitian adalah dokumentasi. Data penelitian ini dikumpulkan melalui internet atau situs website yang berhubungan dengan penelitian ini.

\section{Teknik Analisis}

Teknik analisis data yang digunakan untuk mengetahui factor-faktor yang mempengaruhi profibabilitas adalah dengan analisis regresi linier berganda untuk meyakinkan bahwa variable bebas mempunyai pengaruh terhadap variable terikat,

\section{HASIL PENELITIAN}

\section{Analisis Statistik Deskriptif}

Adapun deskriptif masing-masing variabel penelitian dapat dijelaskan sebagai berikut:

Tabel 1

Deskriptif Variabel Penelitian

Descriptive Statistics

\begin{tabular}{|l|r|r|r|r|r|}
\hline & $\mathrm{N}$ & Minimum & Maximum & Mean & $\begin{array}{c}\text { Std. } \\
\text { Deviation }\end{array}$ \\
\hline CAR & 40 & 10.05 & 48.97 & 18.5800 & 6.49018 \\
FDR & 40 & 51.97 & 127.30 & 85.2743 & 13.58563 \\
ROA & 40 & -4.96 & 4.74 & 1.4525 & 1.69319 \\
Valid N & 40 & & & & \\
(listwise) & & & & & \\
\hline
\end{tabular}

Variabel Capital Adequacy Ratio (CAR) merupakan rasio yang digunakan untuk mengukur kemampuan bank dalam mempertahankan modal yang mencukupi dan kemampuan bank dalam mengidentifikasi, mengukur, mengawasi, dan mengontrol risiko-risiko yang timbul yang dapat berpengaruh terhadap besarnya modal bank. Pada penelitian ini diperoleh nilai CAR minimum sebesar 10,05 dengan nilai maksimum sebesar 48,97 kemudian diperoleh nilai rata - rata sebesar 18.58 yang berarti bahwa secara umum tingkat kemampuan perusahaan perbankan dalam kecukupan modal sudah baik karena sudah lebih besar dari ketentuan Bank Indonesia sebesar 8\%.

Variabel Financing to Deposit Ratio (FDR) merupakan rasio yang digunakan untuk mengukur likuiditas suatu bank dalam membayar kembali penarikan dana yang dilakukan deposan dengan mengandalkan kredit yang 
diberikan sebagai sumber likuiditasnya. Pada penelitian ini diperoleh nilai FDR minimum sebesar 51,97 dengan nilai maksimum sebesar 127,30 kemudian diperoleh nilai rata - rata sebesar 85,2743 yang berarti bahwa secara umum tingkat likuiditas perusahaan perbankan sudah baik karena terletak antara $80 \%$ $110 \%$.

Profitabilitas (ROA) merupakan rasio yang digunakan untuk mengukur kemampuan perusahaan dalam menghasilkan laba yang berasal dari aktivitas investasi pada perusahaan perbankan. Pada penelitian ini diperoleh nilai ROA minimum sebesar -4,96 dengan nilai maksimum sebesar 4,74 kemudian diperoleh nilai rata - rata sebesar 1,4525 yang berarti bahwa secara umum tingkat kemampuan perusahaan perbankan dalam menghasilkan laba sangat rendah.

\section{Uji Asumsi Klasik}

Uji Normalitas

Uji normalitas dilakukan untuk mengetahui apakah dalam suatu model regresi nilai residu dari regresi mempunyai distribusi secara normal atau tidak. Pengujian normalitas dilakukan melihat dari digunakan untuk melihat dari grafik/ normal PP Plot yang terbentuk. Deteksi normalitas data dengan melihat penyebaran itemitem pada sumbu diagonal dari grafik normal P-P Plot, dengan dasar keputusan, apabila item-item menyebar disekitar garis diagonal dan mengikutu garis diagonal, maka model regresi memenuhi asumsi. Berdasarkan hasil pengolahan data diperoleh hasil uji sebagai berikut:

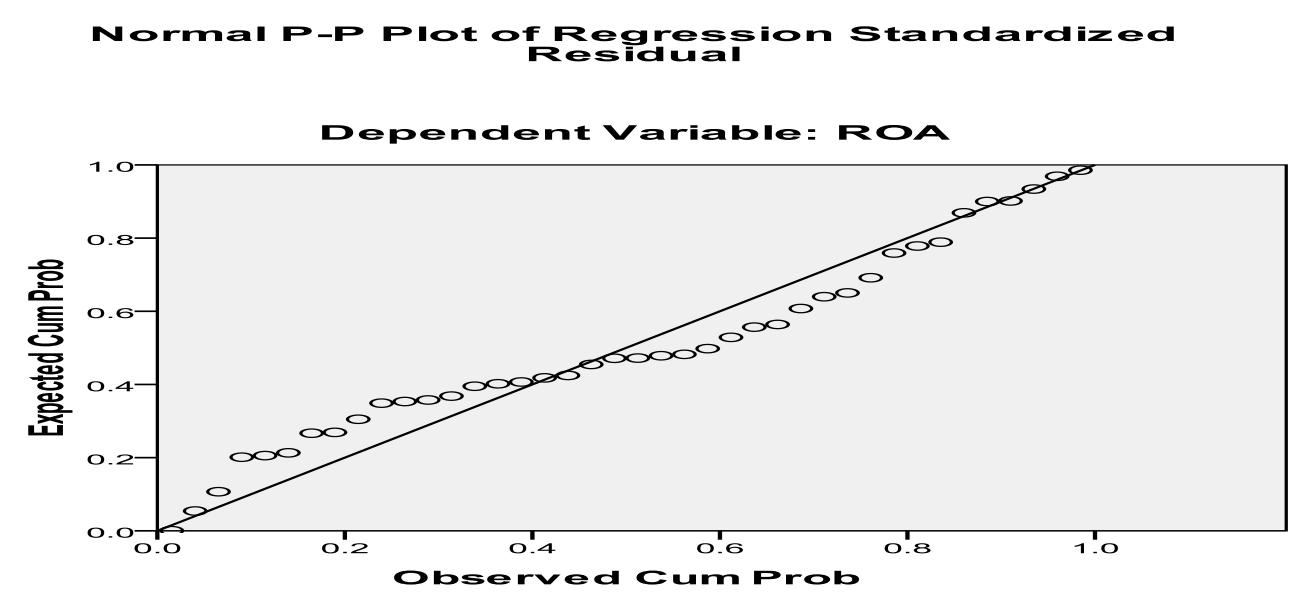

Gambar 2

Hasil Uji Normalitas

Berdasarkan tabel di atas terlihat bahwa penyebaran titik-titik menyebar disekitar garis diagonal dan penyebarannya mengikuti garis diagonal. Hal ini berarti bahwa data dalam penelitian ini berdistribusi normal.

\section{Uji Heteroskedastisitas}

Uji heteroskedastisitas digunakan untuk mengetahui apakah dalam model regresi terjadi ketidaksamaan varians dari residual suatu pengamatan ke pengamatan lain.jika varians dari residual satu pengamatan ke pengamatan tetap 
maka disebut homokedastisitas dan jika berbeda disebut heterokedaktisitas. Model regresi yang baik adalah yang homokedastisitas atau tidak terjadi heterokedastisitas.

Cara untuk mendeteksi adanya heterokedastisitas dapat dilakukan dengan Pengujian Scatterplot bertujuan untuk mengetahui dalam model regresi terjadi ketidaksamaan varians dari residual pengamatan ke pengamatan yang lain dengan dasar penngambilan keputusan adalah Jika tidak ada pola yang jelas serta titiktitik menyebar di atas dan dibawah angka 0 pada sumbu Y, maka tidak terjadi heteroskedastisitas.

Berdasarkan pengolahan data menggunakan program SPPS diperoleh hasil sebagai berikut:

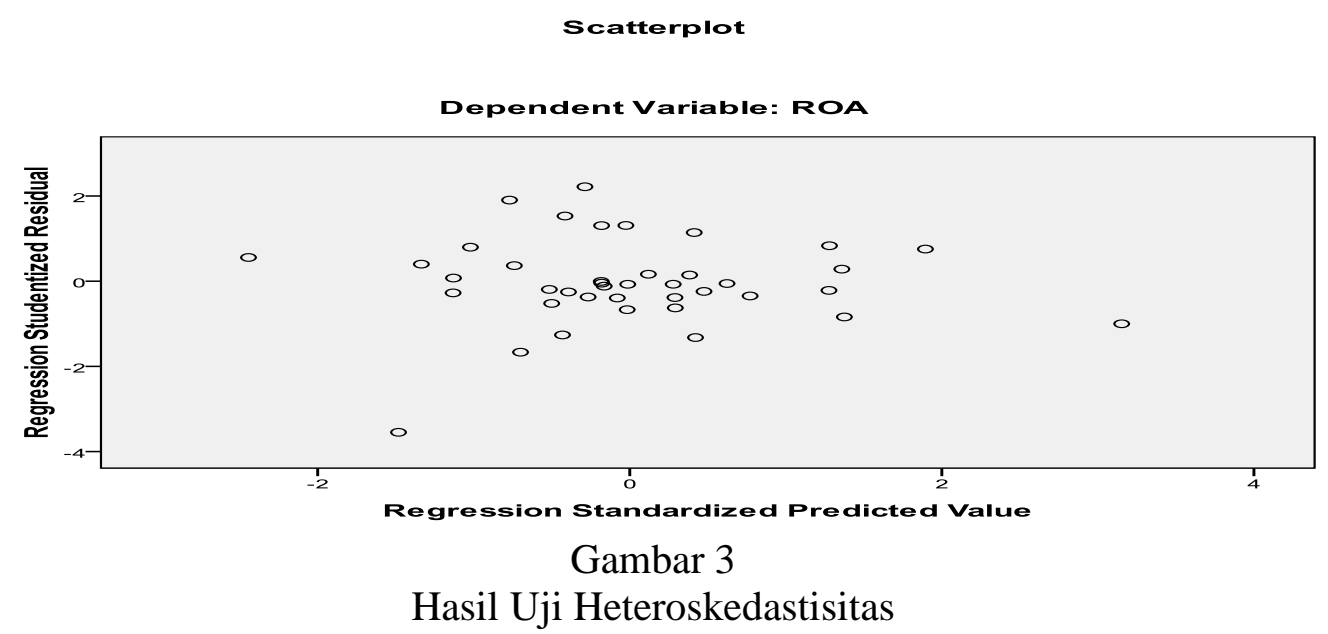

Berdasarkan gambar di atas terlihat titik-titik menyebar di atas dan di bawah angka 0 pada sumbu Y dan tidak ada pola yang jelas. Hal ini menjelaskan bahwa tidak terdapat gangguan heteroskedastisitas.

\section{Uji Multikolinieritas}

Pengujian ini dimaksudkan untuk mengetahui apakah terdapat korelasi yang tinggi antara vaiabel-variabel bebas dalam model yang digunakan. Apabila terdapat korelasi yang tinggi sesama variabel bebas tersebut, maka salah satunya dieliminir (dikeluarkan) dari model regresi berganda atau menambah variabel bebasnya. Korelasi antara variabel independen dapat dideteksi dngan menggunakan Variabel Inflaksi Faktor (VIF) dengan kriteriaa yaitu:

1. Jika angka tolerance diatas 0,1 dan $\mathrm{VIF}<10$ dikatakan tidak terdapat gejala multikolinearitas.

2. Jika angka tolerance dibawah 0,1 dan VIF $>10$ dikatakan terdapat gejala multikolinearitas.

Berdasarkan pengolahan data menggunakan program SPSS diperoleh hasil sebagai berikut:

Tabel 2

Hasil Uji Multikolinieritas 


\begin{tabular}{|c|c|c|c|}
\hline \multirow{2}{*}{\multicolumn{2}{|c|}{ Model }} & \multicolumn{2}{|c|}{$\begin{array}{c}\text { Collinearity } \\
\text { Statistics }\end{array}$} \\
\hline & & Tolerance & VIF \\
\hline \multirow[t]{3}{*}{1} & $($ Constant $)$ & & \\
\hline & CAR & .920 & 1.087 \\
\hline & FDR & .920 & 1.087 \\
\hline
\end{tabular}

a. Dependent Variable: ROA

Berdasarkan table di atas terlihat nilai VIF untuk variabel CAR dan FDR masing-masing sebesar 1,087 lebih kecil dari 10. Hal ini menjelaskan bahwa tidak terdapat gangguan multikolinieritas.

\section{Uji Autokorelasi}

Uji korelasi merupakan pengujian asumsi dalam regresi dimana variabel dependen yaitu transfer pricing tidak berkorelasi dengan dirinya sendiri, artinya bahwa nilai variabel dependen tidak berhubungan dengan nilai variabel itu sendiri, baik nilai periode sebelumnya atau nilai periode sesudahnya. Untuk mendiagnosis adanya korelasi dalam suatu model regresi dilakukan dengan pengujian DurbinWatson (D-W). Hasil perhitungan Durbin-Watson (d) dibandingkan dengan nilai d pada $\alpha$ maka $d$ memiliki dua nilai, yaitu nilai batas atas $\left(\mathrm{d}_{\mathrm{u}}\right)$ dan nilai batas bawah $\left(\mathrm{d}_{\mathrm{L}}\right)$ untuk berbagai nilai $\mathrm{n}$ dan $\mathrm{k}$.

Jika $\quad \mathrm{d}<\mathrm{d}_{\mathrm{L}}$; maka terjadi autokorelasi positif

$\mathrm{d}>4-\mathrm{d}_{\mathrm{L}}$; maka terjadi auto koelasi negative

$\mathrm{d}_{\mathrm{u}}<\mathrm{d}<4-\mathrm{d}_{\mathrm{u}}$; maka tidak terjadi autokorelasi

$\mathrm{d}_{\mathrm{L}} \leq \mathrm{d} \leq \mathrm{d}_{\mathrm{u}}$ atau $4-\mathrm{d}_{\mathrm{u}} \leq \mathrm{d} \leq 4-\mathrm{d}_{\mathrm{L}} ;$ maka pengujian tidak meyakinkan.

Berdasarkan pengolahan data menggunakan program SPSS diperoleh hasil sebagai berikut:

Tabel 3

Hasil Uji Autokorelasi

\begin{tabular}{|l|r|}
\hline Model & Durbin-Watson \\
\hline 1 & 1.933 \\
\hline
\end{tabular}

a. Predictors: (Constant), FDR, CAR

b. Dependent Variable: ROA

Tabel di atas menunjukkan bahwa nilai DW sebesar 1,933 kemudian nilai dU sebesar 1,600. Hal ini berarti nilai DW terletak antara dU $<$ DW $<4-$ dU $(1,600<1,933<2,400)$. Hal ini berarti bahwa tidak terjadi autokorelasi. 


\section{Analisis Regresi Berganda}

Untuk mencari faktor-faktor yang berpengaruh terhadap variabel ROA (Y) digunakan analisis regresi berganda. Berdasarkan pengolahan data menggunakan program SPSS diperoleh hasil sebagai berikut:

Tabel 4

Hasil Uji Regresi Berganda

\begin{tabular}{|c|c|c|c|c|c|c|}
\hline \multirow{2}{*}{\multicolumn{2}{|c|}{ Model }} & \multicolumn{2}{|c|}{$\begin{array}{l}\text { Unstandardized } \\
\text { Coefficients }\end{array}$} & \multirow{2}{*}{$\begin{array}{c}\begin{array}{c}\text { Standardized } \\
\text { Coefficients }\end{array} \\
\text { Beta }\end{array}$} & \multirow[b]{2}{*}{$\mathrm{T}$} & \multirow[b]{2}{*}{ Sig. } \\
\hline & & B & Std. Error & & & \\
\hline 1 & (Constant) & -3.915 & 2.035 & & -1.923 & .062 \\
\hline & CAR & .061 & .041 & .232 & 1.480 & .147 \\
\hline & FDR & .050 & .020 & .399 & 2.542 & .015 \\
\hline
\end{tabular}

a. Dependent Variable: ROA

Sumber : Data yang diolah, 2015 berikut:

Berdasarkan tabel di atas, diperoleh persamaan garis regresi sebagai

$$
Y=-3,915+0,061 X_{1}+0,050 X_{2}
$$

Persamaan di atas dapat dijelaskan sebagai berikut:

1. Nilai konstanta (a) sebesar -3,915 menunjukkan bahwa tanpa adanya CAR $\left(\mathrm{X}_{1}\right)$ dan FDR $\left(\mathrm{X}_{2}\right)$ maka profitabilitas yang diperoleh perusahaan perbankan yang terdaftar di BEI sebesar $-3,915 \%$. Hal ini menjelaskan bahwa perusahaan perbankan yang terdaftar di BEI selama tahun 2014 tidak memperoleh laba (rugi).

2. Nilai koefisien regresi CAR sebesar 0,061 menunjukkan bahwa bila CAR meningkat sebesar $1 \%$, maka profitabilitas yang diperoleh perusahaan perbankan yang terdaftar di BEI juga akan meningkat sebesar $0,061 \%$ dengan asumsi variabel bebas lainnya dianggap konstan (0).

3. Nilai koefisien regresi FDR sebesar 0,050 menunjukkan bahwa bila FDR meningkat sebesar 1\%, maka profitabilitas yang diperoleh perusahaan perbankan yang terdaftar di BEI juga akan meningkat sebesar $0,050 \%$ dengan asumsi variabel bebas lainnya dianggap konstan (0).

\section{Uji Hipotesis}

Pengujian hipotesis dilakukan dengan cara membandingkan antara tingkat signifikansi (sig) dengan tingkat kesalahan $(\alpha)=5 \%$. Apabila tingkat signifikansi yang diperoleh lebih kecil dari 0,05 variabel independen tersebut berpengaruh terhadap variabel dependennya. Tabel berikut menunjukkan hasil pengujian hipotesis dalam penelitian ini:

Tabel 5

Hasil Uji Hipotesis

\begin{tabular}{|l|c|c|c|c|}
\hline Model & $\begin{array}{c}\text { Unstandardized } \\
\text { Coefficients }\end{array}$ & $\begin{array}{c}\text { Standardized } \\
\text { Coefficients }\end{array}$ & $\mathrm{T}$ & Sig. \\
\hline
\end{tabular}




\begin{tabular}{|rl|r|r|r|r|r|}
\hline & \multicolumn{1}{|c|}{ B } & Std. Error & \multicolumn{1}{c|}{ Beta } & & \\
\hline 1 & (Constant) & -3.915 & 2.035 & & -1.923 & .062 \\
& CAR & .061 & .041 & .232 & 1.480 & .147 \\
& FDR & .050 & .020 & .399 & 2.542 & .015 \\
\hline
\end{tabular}

a. Dependent Variable: ROA

Sumber: Data yang diolah, 2015

Berdasarkan tabel di atas maka dapat dilakukan pengujian hipotesis untuk masing-masing variabel bebas terhadap variabel terikat sebagai berikut:

a. Pengaruh Capital Adequacy Ratio (CAR) Terhadap Profitabilitas (ROA)

Berdasarkan table 5 terlihat bahwa tingkat signifikansi untuk variabel CAR sebesar 0,147 lebih besar dari $\alpha=0,05$ maka dapat dinyatakan bahwa Ho diterima yang berarti tidak terdapat pengaruh yang signifikan antara variabel Capital Adequacy Ratio (CAR) terhadap Profitabilitas (ROA).

b. Pengaruh Financing to Deposit Ratio (FDR) Terhadap Profitabilitas (ROA)

Berdasarkan table 5 terlihat bahwa tingkat signifikansi untuk variabel Financing to Deposit Ratio (FDR) sebesar 0,015 lebih kecil dari $\alpha=0,05$ maka dapat dinyatakan bahwa Ho ditolak dan Ha diterima yang berarti terdapat pengaruh yang signifikan antara variabel Financing to Deposit Ratio (FDR) Terhadap Profitabilitas (ROA). Nilai koefisien regresi variabel Financing to Deposit Ratio (FDR) bertanda positif yang berarti semakin tinggi nilai Financing to Deposit Ratio (FDR) maka akan semakin tinggi pula nilai variabel Profitabilitas (ROA) begitupula sebaliknya semakin rendah Financing to Deposit Ratio (FDR) maka akan semakin rendah nilai Profitabilitas (ROA).

c. Pengaruh Capital Adequacy Ratio (CAR), Financing to Deposit Ratio (FDR), Biaya Operasional per Pendapatan Operasional (BOPO) Terhadap Profitabilitas (ROA).

Berdasarkan pengolahan data menggunakan program SPSS diperoleh hasil sebagai berikut:

Tabel 6

Hasil Uji F

\begin{tabular}{|c|c|c|c|c|c|c|}
\hline \multicolumn{7}{|c|}{ ANOVA $^{b}$} \\
\hline \multicolumn{2}{|c|}{ Model } & $\begin{array}{l}\text { Sum of } \\
\text { Squares }\end{array}$ & Df & Mean Square & $\mathrm{F}$ & Sig. \\
\hline 1 & Regression & 17.987 & 2 & 8.993 & 3.547 & $.039^{\mathrm{a}}$ \\
\hline & Residual & 93.821 & 37 & 2.536 & & \\
\hline & Total & 111.808 & 39 & & & \\
\hline
\end{tabular}

a. Predictors: (Constant), FDR, CAR

b. Dependent Variable: ROA

Sumber : Data yang diolah, 2015 
Berdasarkan tabel di atas diketahui nilai signifikansi $\mathrm{F}$ sebesar 0,039 lebih kecil dari dari $\alpha=0,05$ yang berarti bahwa secara bersama - sama variabel Capital Adequacy Ratio (CAR) dan Financing to Deposit Ratio (FDR) berpengaruh signifikan terhadap variabel Profitabilitas (ROA).

d. Uji Korelasi (R) dan Uji Koefisien Determinasi $\left(\mathrm{R}^{2}\right)$

Selanjutnya untuk melihat besarnya hubungan dan seberapa besar pengaruh variabel Capital Adequacy Ratio (CAR) dan Financing to Deposit Ratio (FDR) dengan Profitabilitas (ROA) dapat dilihat pada tabel model summary sebagai berikut:

Tabel 7

Hasil Uji R dan $\mathrm{R}^{2}$

Model Summary ${ }^{\mathrm{b}}$

\begin{tabular}{|l|r|r|r|r|r|}
\hline Model & \multicolumn{1}{|c|}{$\mathrm{R}$} & R Square & $\begin{array}{c}\text { Adjusted R } \\
\text { Square }\end{array}$ & $\begin{array}{c}\text { Std. Error of } \\
\text { the Estimate }\end{array}$ & $\begin{array}{c}\text { Durbin- } \\
\text { Watson }\end{array}$ \\
\hline 1 & $.401^{\mathrm{a}}$ & .161 & .116 & 1.59239 & 1.933 \\
\hline
\end{tabular}

a. Predictors: (Constant), FDR, CAR

b. Dependent Variable: ROA

Sumber: Data yang diolah, 2015

Berdasarkan tabel 7 di atas diketahui nilai R sebesar 0,401 hal ini berarti bahwa variabel Capital Adequacy Ratio (CAR) dan Financing to Deposit Ratio (FDR) secara bersama-sama mempunyai hubungan yang lemah dengan variabel Profitabilitas (ROA).

Kemudian diketahui nilai Adjusted R Square sebesar 0,161 yang berarti bahwa variabel Capital Adequacy Ratio (CAR) dan Financing to Deposit Ratio (FDR) mempengaruhi variabel Profitabilitas (ROA) sebesar 16,1\% sedangkan sisanya sebesar $83,9 \%$ dipengaruhi oleh faktor lain diluar penelitian ini seperti BOPO dan lain-lain.

\section{Pembahasan Hasil Penelitian}

\section{Pengaruh Capital Adequacy Ratio (CAR) Terhadap Profitabilitas (ROA)}

Variabel Capital Adequacy Ratio (CAR) tidak berpengaruh signifikan terhadap variabel Profitabilitas (ROA), hal ini ditunjukkan dengan nilai signifikansi yang lebih besar dari 0,05. Pada penelitian ini diperoleh nilai CAR minimum sebesar 10,05 dengan nilai maksimum sebesar 48,97 kemudian diperoleh nilai rata - rata sebesar 18.58 yang berarti bahwa secara umum tingkat kemampuan perusahaan perbankan dalam kecukupan modal sudah baik karena sudah lebih besar dari ketentuan Bank Indonesia sebesar 8\%.

Hasil penelitian ini mengindikasikan bahwa besar kecilnya kecukupan modal bank (CAR) belum tentu menyebabkan besar kecilnya keuntungan bank. Bank yang memiliki modal besar namun tidak dapat menggunakan modalnya itu secara efektif untuk menghasilkan laba, maka modal yang besar pun tidak berpengaruh secara signifikan terhadap profitabilitas bank. Selain itu peraturan Bank Indonesia yang mensyaratkan CAR minimal sebesar $8 \%$ mengakibatkan 
bank-bank selalu berusaha menjaga agar CAR yang dimiliki sesuai dengan ketentuan. Lebih dari pada itu, jika dilihat kondisi empiris dari obyek penelitian maka akan tampak bahwa sebagian besar bank syariah mempunyai CAR diatas $8 \%$ bahkan sampai melebihi angka 20\%. Hal ini disebabkan karena adanya penambahan modal untuk mengantisipasi perkembangan skala usaha yang berupa ekspansi kredit (pembiayaan). Namun pada kenyataannya sampai saat ini bank belum dapat melempar pembiayaan sesuai dengan yang diharapkan. ${ }^{20}$

Hasil penelitian ini sejalan dengan penelitian yang dilakukan oleh Millatina Arini (2012) dengan judul "Analisis Faktor - Faktor yang Mempengaruhi Profitabilitas Perbankan (Studi Bank Umum yang Listed di BEI Tahun 2007 - 2010). Hasil penelitiannya menunjukkan bahwa variabel Capital Adequacy Ratio (CAR) tidak berpengaruh signifikan terhadap variabel Profitabilitas (ROA).

\section{Pengaruh Financing to Deposit Ratio (FDR) Terhadap Profitabilitas (ROA)}

Berdasarkan hasil penelitian diketahui bahwa terdapat pengaruh yang signifikan antara variabel Financing to Deposit Ratio (FDR) Terhadap Profitabilitas (ROA). Pada penelitian ini diperoleh nilai FDR minimum sebesar 51,97 dengan nilai maksimum sebesar 127,30 kemudian diperoleh nilai rata rata sebesar 85,2743 yang berarti bahwa secara umum tingkat likuiditas perusahaan perbankan sudah baik karena terletak antara $80 \%-110 \%$.

Financing to Deposit Ratio merupakan rasio yang digunakan untuk mengukur likuiditas suatu bank dalam membayar kembali penarikan dana yang dilakukan deposan dengan mengandalkan kredit yang diberikan sebagai sumber likuiditasnya, yaitu dengan cara membagi jumlah kredit yang diberikan oleh bank terhadap dana pihak ketiga.

Semakin tinggi FDR maka semakin tinggi dana yang disalurkan ke dana pihak ketiga. Dengan penyaluran dana pihak ketiga yang besar maka pendapatan bank (ROA) akan semakin meningkat, sehingga FDR berpengaruh positif terhadap ROA.

\section{SIMPULAN DAN SARAN \\ Simpulan}

Berdasarkan data yang telah dikumpulkan dan pengujian dengan analisis regresi yang telah dilakukan terhadap permasalahan. Maka dapat diambil kesimpulan sebagai berikut:

1. Variabel Capital Adequacy Ratio (CAR) tidak berpengaruh signifikan terhadap variabel Profitabilitas (ROA).

2. Variabel Financing to Deposit Ratio (FDR) berpengaruh signifikan Terhadap Profitabilitas (ROA).

${ }^{20}$ Dhika Rahma Dewi. Faktor-Faktor yang mempengaruhi Profitabilitas Bank Syariah di Indonesia. 
3. Variabel Capital Adequacy Ratio (CAR) dan Financing to Deposit Ratio (FDR) secara bersama-sama berpengaruh signifikan terhadap variabel Profitabilitas (ROA).

\section{Saran}

Berdasarkan hasil penelitian yang peneliti lakukan maka dapat diberikan saran kepada BEI (Bursa Efek Indonesia) yaitu:

1. Untuk menjaga tingkat modal bank (CAR) sebaiknya perusahaan lebih memperhatikan jumlah modal yang dimiliki oleh perusahaan, karena modal merupakan faktor terpenting yang harus dimiliki oleh bank. Untuk mengantisipasi perkembangan skala usaha expansi kredit atau pinjaman yang diberikan.

2. Karena FDR memiliki pengaruh yang terhadap profitabilitas, maka sebaiknya pihak perbankan dapat menjaga keseimbangan rasio penyaluran pembiayaan (FDR) untuk meningkatkan profitabilitas yang diterima oleh bank syariah agar berada diantara batas yang ditetapkan oleh bank indonesia. Bentuk penyaluran yang diberikan diharapkan tidak melebihi jumlah penghimpunan dana yang diterima oleh perbankan. Bank syariah harus mampu memberikan pembiayaan lebih selektif kepada nasabah. Karena, penyaluran pembiayaan yang tidak efisien bukan tidak mungkin berujung pada pembiayaan bemasalah.

3. Bagi peneliti lainnya diharapkan agar dapat mengeksplorasi atau mencari faktor apa saja yang dapat mempengaruhi profitabilitas selain variabelvariabel yang diteliti pada penelitian ini. Peneliti lainnya dapat meneliti dengan variabel,jumlah sampel serta tempat dan waktu penelitian yang berbeda.

\section{DAFTAR PUSTAKA}

Brigham. 1993. Intermediate Financial Management, Fourth , Fort Word, The Dyrden Press,: Harcourt Brace College Publisher

Defri. 2012. Pengaruh Capital Adequacy Ratio (CAR), Likuiditas dan Efisiensi Operasional Terhadap Profitabilitas Perusahaan Perbankan yang Terdaftar di BEI. Jurnal Manajemen. Vol 1. No 1.

Dendawijaya. 2009. Manajemen Perbankan. Penerbit Ghalia Indonesia. Jakarta.

Dhika Rahma Dewi. Faktor-Faktor yang mempengaruhi Profitabilitas Bank Syariah di Indonesia.

Dwi Prastowo. 2008. Analisis Laporan Keuangan: Konsep dan Aplikasi (Edisi Kedua). Yogyakarta: UPP STIM YKPN

Giulio Battazzi, Angelo Secchi, and Federico Tamagni. "Productivity, Profitabilty, and Financial Performance". Oxford JournalsEconomics \& Social Sciences Industrial and Corporate Change Volume 17, Issue 4Pp. $711-751$

Hanafi dan Halim. 2003. Analisis Laporan Keuangan, Edisi. Kedua, Yogyakarta : STIE YKPN

Husnan. 2001. Manajemen Keuangan Teori dan Penerapan. (keputusan Jangka Pendek), Edisi keempat, BPFE, Yogyakarta.

Martono dan Harjito. 2011. Manajemen Keuangan, Yogyakarta, Ekonisia 
Michelle \& Megawati. 2005. Tingkat Pengembalian Investasi Dapat Diprediksi Melalui Profitabilitas, Likuiditas, dan Leverage. Kumpulan Jurnal Ekonomi_com.

Muhammad. 2005. Bank Syariah Problem dan Proses Perkembangan di Indonesia. Graha Ilmu:Yogyakarta.

Munawir. 2004. Analisis Laporan Keuangan, Edisi Ke-4, Liberty, Yogyakarta

Nugroho. 2011. Analisis Rasio Keuangan untuk menilai Kinerja Keuangan Perbankan Studi Empiris Bank Go Publik 2003-2004. Skripsi Akuntansi Universitas Muhammadiyah Surakarta

Rivai. 2007. Bank and Financial Institution Manajement, Jakarta : PT. Rajagrafindo Persada

Robert C. Fink dan Ann Harrison. 1999. Business Return on Investment, Journal of Return On Investment, Computerworld; Jun 21; vol 33, Iss 25; ABI/INFORM Global, pg. 72. (on line)

Shapiro. 1991. Analisis Pengaruh Return On Equity, Insider Ownership, Investment Opportunity Set, Firm Size, Cash Flo, dan Debt Ratio terhadap Dividend Payout Ratio (Studi Empiris Perusahaan Manufaktur di BEI Periode 2004-2007)”. Skripsi Ekonomi Akuntansi, Universitas Diponegoro.

Sukarno \& Syaichu. 2006. Analisis Faktor - Faktor yang Mempengaruhi Kinerja Bank Umum di Indonesia. Jurusan Manajemen Falkutas Ekonomi dan Bisnis Universitas Diponegoro. Jurnal Studi Manajemen dan Organisasi. Volume 3, Nomer 2.

Susilo. 2000. Bank dan Lembaga Keuangan Lain, Salemba Empat,. Jakarta

Syamsudin. 2004. Manajemen Keuangan Perusahaan. Jakarta : PT Raja Grafindo Persada. 